\title{
Technology-Enhanced Language Learning (TELL): A Review of Resourses and Upshots
}

\author{
Afsaneh Ghanizadeh, Azam Razavi, Safoura Jahedizadeh \\ Imam Reza International University, \\ Khorasan Razavi, Mashhad, Sanabaad, Daneshgah, 91735-553, Iran
}

Email: ghanizadeafsane@yahoo.com; a.ghanizadeh@imamreza.ac.ir

\author{
Keywords: Technology; Language Education; Meta-analysis
}

\begin{abstract}
The purpose of this paper is to investigate the effectiveness of using technology in improving learning in general and language learning in particular. To do this, a review of recent studies in technology-enhanced learning with a specific focus on technology-enhanced language learning (TELL) was conducted. It was revealed that using different kinds of technology can have positive impacts on students' progress in different educational contexts in general. These benefits are multidimensional and comprehensive encompassing cognitive, metacognitive, and affective domains of learning. In the case of language learning, the same results were obtained. The findings showed that technology-based language instruction can be used effectively as teacher-delivered instruction. It was also indicated that technology can have a positive effect on language learning when its potential capacities are incorporated into pedagogy and curriculum. Besides, it was demonstrated that students' listening, writing, speaking, and reading skills were enhanced and the technology was seen to have positive impact on sub-skills such as grammar and vocabulary learning. Problem solving as one of the most significant strategies in language learning was also improved. Generally speaking, utilizing technology in the EFL/ESL context provided enjoyable environment for students to learn English. These benefits and consequences are not restricted to any specific age and gender groups.
\end{abstract}

\section{INTRODUCTION}

This review study is deliberated to contend with the effectiveness of using technology in language education for future investment decisions. Researchers, material developers, and teachers are interested to know what has been done and what we already know about TELL so that they can make educated decisions in selecting the appropriate technology to use in teaching process.

Technology encompasses a wide range of tools as multimedia computers, Internet, mobiles, smart boards, videotapes, online chartrooms, web pages, interactive audio conferencing, and so on. To investigate the effectiveness of using technology in language learning, it is irrational to expect any single study to tell us all things. However, a comprehensive review of many studies can get us closer to an answer (e.g., Cavanaugh, 2001; Chapelle, 1997; Lou, Abrami, \& d'Apollonia, 2001; Salaberry, 2001). For finding the effectiveness of using technology in language education it is need to analyze findings of numerous empirical studies as a research method called meta-analysis (Glass, 1977; Hedges \& Olkin, 1985; Lyons, 1995a),. Meta-analysis helps us develop a careful map of past and current studies in the field of technology and language education. This review attempts to investigate the overall effectiveness of uses of technology in language education through metaanalysis.

\section{A. Defining Technology}

The term technology in this study refers to the use of systems that rely on computer chips, digital applications, and networks in all of their forms. These systems are not limited to the commonly recognized desktop and laptop computers: Almost all electronic devices these days include an embedded computer chip of some sort (DVD players, data projectors, interactive whiteboards, etc.). 
Mobile devices that employ a computer at their core (cell phones, personal digital assistants [PDAs], MP3 players, etc.) will undoubtedly occupy a more central role in language teaching and learning in the years to come (TESOL technology standard frame work, $p$ 45).

\section{B. Role of Technology in Education}

Technology has several fundamental roles in language education; it is used as resources, delivery system, or productivity. Computer programs seems to be most effective in supporting student centered learning as the technology can provide scaffolds for students with special needs, and interests, and it support factual knowledge acquisition, and create new learning experiences for students (Pedersen \& Liu, 2003). Besides, if computers serve as resources, significant learning gains were found (Wegerif, 2004).

\section{Type of Technology, Software, and Objective of Technology}

Type of technology refers to the carriers (e.g. laptops, PCs, PDAs...etc.) of the instructional material while software is the type of instructional material itself (e.g. tutorial, drill \& practice, exploratory environment...etc). For example, laptop programs were found to be effective in student engagement (Penuel, 2006) and academic achievement (Nabah, 2012) or by using multimedia talking books beginning readers can learn to read (Chera \& Wood, 2003; Doty, Popplewell, Byers, 2001).

\section{Effectiveness of Technologies in Language Learning}

It is essential in language learning to expose learners with authentic, comprehensible input to engage them in teaching and learning process (Krashen, 1998). To do this, demanding materials in the target language for successful language learning is necessary, but to some extent is limited.

So, language educators believe that by using information and communication technologies (ICT), we can solve this problem (Egbert, Chao, \& Hanson-Smith, 1999; Hanson-Smith, 1999; Salaberry, 2001).

The uses of technology provide qualified access and exposure to linguistic and cultural materials .For example using digital multimedia technologies enhance access efficiently than a single medium alone ((Hanson-Smith, 1999; Thorton \& Dudley, 1996). Traore\& Blankson(2011) used audio-visual technologies in teaching English and found that it helped students to learn English more than other group using single technology .

Technology uses enhance authenticity using video and the internet. These kind of materials provide a natural and context-rich linguistic and cultural situation that enable the learners to access authentic target language that can reflect cultural changes effectively than printed sources (Bacon \& Finnemann, 1990; Hanson-Smith, 1999; Herron, Cole, Corrie, \& Dubreil, 1999; Herron, Dubreil, Cole, \& Corrie, 2000; Kitajima \& Lyman-Hager, 1998; Lafford \& Lafford, 1997; Lee, 1998; Weyers, 1999). Patel (2013) studied the effectiveness of authentic materials on learning communication skills.

\section{E. Providing Opportunities for Communication}

Successful language learning requires providing opportunities and engaging learners in authentic communication in the target language. ICT has again been used in many different ways to create opportunities for language learners to communicate in the target language (Hanson-Smith, 1999; Kelm, 1998; Muyskens, 1998; Warschauer \& Kern, 2000). 


\section{METHOD}

\section{A. Search Procedures and Criteria for Inclusion}

The current study reviews a thorough collection of recent articles towards the effects of using technology on students' progress in two domains of general education and English as a foreign/ second language. The research encompasses plethora of quantitative, qualitative and mixed methods studies investigating the effect of technology on learners' improvement. These studies were published between 2004 and 2014 and 30 articles which met the following criteria were investigated for this review: 1. Evaluating the effect of technology on students' progress was the main purpose of the study. 2. The context of the study was general or second/ foreign language learning (i.e. in the area of education) and 3. Positive effects of utilizing technology were described.

The studies not written in English were not included in this synthesis, nor were studies that were master or doctoral dissertations, and book chapters. Finally, a total of 30 articles from the following journals were selected for this review: Journal of Language and Translation, The International Arab Journal of Information Technology, Journal of Academic and Applied Studies, Advances in English Linguistics (AEL), The JALT CALL Journal, Teaching of Psychology, Mathematics Education Trends and Research, Language Learning \& Technology, Computers \& Education, Discourse: Studies in the Cultural Politics of Education, European Online Journal of Natural and Social Sciences, Interdisciplinary Journal of Contemporary Research in Business, International Journal of Research Studies in Educational Technology, The Turkish Online Journal of Educational Technology, Journal of Second and Multiple Language Acquisition, Journal of Language Teaching and Research, Journal of Advances in English Language Teaching, Journal of Arts and Humanities, International Journal of Education and Development using Information and Communication Technology, International Journal of Scientific Research and Reviews, Social and Behavioral Sciences, Computers \& Education, Australian Journal of Language and Literacy, Eurasia Journal of Mathematics, Science, and Technology Education, English Language and Literature Studies, Journal of Basic and Applied Scientific Research, International Journal of Advancements in Research \& Technology.

\section{B. Coding and Analysis}

The selected studies were coded based on a coding scheme (table 1) used in a number of previous reviews. To analyze the studies, the characteristics of each study were coded and classified into two categories regarding the purpose of the study. As Creswell (1994) stated the central aim of a review is to summarize the previous research toward a specific topic and to identify the issues which need further investigation. Thus, the present review provides in-depth knowledge about the effect of technology on students' progress.

To provide a systematic review, selected studies were divided into two categories: the general education and language education. The type of technology was specified and the ramifications of each study were identified through these two categories. 
Table 1. Coding Scheme for Primary Studies
1.Publication
a. Name of the article and authors
b. Year of publication
2. Context of the study
a. General education/ language education
b. Number of participants
c. Participants' age (average)
d. Participants' gender
e. Educational institution (in which teachers have taught)

3. Country

4. Technology used

5. Effectiveness of using technology

6. Data Analysis

7. Out comes (findings)

\section{RESULTS}

The selected studies for the current review encompass research carried out between 2004 and 2014. The research was conducted in variety of educational contexts: from elementary school to university. $56 / 6 \%$ of the studies were carried out among students of a general course and $43 / 3 \%$ of the articles were conducted in an EFL/ ESL context. In the studies we reviewed, for data collection, two kinds of instruments were mainly used to measure the effect of technology on students' learning: questionnaires and interview.

Table 2 demonstrates the studies carried out in the domain of general education.

Table 2. Studies on the Effect of Technology in a General Course

\begin{tabular}{lllll}
\hline Code & Publication & Educational institution & Country & Data analysis \\
\hline 1 & Omidinia\&Masrom\&Selamat(2013) & Unspecified & Malaysia & Unspecified \\
& Naba'h(2012) & Secondary school & $\begin{array}{l}\text { Saudi } \\
\text { Arabia }\end{array}$ & ANCOVA \\
& & & India & qualitative \\
& & Unsproach
\end{tabular}




\begin{tabular}{|c|c|c|c|c|}
\hline 4 & Soltani (2012) & Unspecified & $\begin{array}{l}\text { Baku, } \\
\text { Azerbaijan }\end{array}$ & Unspecified \\
\hline 5 & Attaran, Alias \&Siraj (2012) & Unspecified & Malaysia & $\begin{array}{l}\text { qualitative } \\
\text { approach }\end{array}$ \\
\hline 6 & Walsh (2010) & primary school & Australia & $\begin{array}{l}\text { online } \\
\text { questionnaires }\end{array}$ \\
\hline 7 & ong (2009) & primary school & Malaysia & ANCOVA \\
\hline 8 & Nomass( 2013) & Unspecified & Libya & Questionnaire \\
\hline 9 & Dlaska(2002) & University & UK & $\begin{array}{l}\text { Qualitative } \\
\text { approach }\end{array}$ \\
\hline 10 & Sharndama (2013) & Unspecified & Nigeria & $\begin{array}{l}\text { Qualitative } \\
\text { approach }\end{array}$ \\
\hline 11 & $\begin{array}{l}\text { Fallahkhair,Pemberton\& } \\
\text { Griffiths(2005) }\end{array}$ & Unspecified & UK & $\begin{array}{l}\text { qualitative } \\
\text { approach }\end{array}$ \\
\hline 12 & Patel (2013) & Unspecified & Unspecified & Qualitative \\
\hline 13 & Liuzhi (2012) & university & China & Qualitative \\
\hline
\end{tabular}

Table 3 is the summary of the studies on English students (as a second or foreign language). 
Table 3. Studies on the effect of technology in an EFL/ ESL context

\begin{tabular}{llllr}
\hline Code & Publication & $\begin{array}{l}\text { Educational } \\
\text { institution }\end{array}$ & Country & Data analysis \\
\hline 14 & Kiliçkaya,\&Seferoğlu(2013) & $\begin{array}{l}\text { Teacher training } \\
\text { course }\end{array}$ & Turkey & $\begin{array}{l}\text { MAXQDA } \\
\text { version } 10\end{array}$
\end{tabular}

\begin{tabular}{|c|c|c|c|c|}
\hline 15 & $\begin{array}{l}\text { Naba'h,Hussain, } \\
\text { Omari,\&Shdeifat(2009) }\end{array}$ & Secondary school & Jordan & ANCOV \\
\hline 16 & Ghorbani,\&Marzban (2013) & High school & Iran & T-test \\
\hline 17 & Hassanabadi, \&Iranban (2013) & High school & Iran & $\begin{array}{l}\text { Descripti } \\
\text { statistics }\end{array}$ \\
\hline 18 & $\begin{array}{l}\text { Bahmani, } \\
\text { \&Ghajari(2013) }\end{array}$ & $\begin{array}{l}\text { primary, junior } \\
\text { and high schools }\end{array}$ & Iran & ANOVA \\
\hline
\end{tabular}

\begin{tabular}{|c|c|c|c|c|}
\hline 19 & $\begin{array}{ll}\text { Rostami, } & \text { Akbari, } \\
\text { \&Ghanizadeh(2014) }\end{array}$ & $\begin{array}{l}\text { junior } \\
\text { school }\end{array}$ & Iran & t-test \\
\hline 20 & $\begin{array}{l}\text { Smith, \& } \\
\text { Woody }(2000)\end{array}$ & university & Georgia & ANCOVA \\
\hline 21 & $\begin{array}{l}\text { Traore,\& } \\
\text { Blankson(2011) }\end{array}$ & High school & China & interviews \\
\hline 22 & $\operatorname{Mehrgan}(2012)$ & university & Iran & KR-21 formula \\
\hline 23 & Iravani,\&Tajik (2012) & High School & Iran & T-test \\
\hline 24 & Wang\&Smith (2013) & university & Japan & $\begin{array}{l}\text { Questionnaire \& } \\
\text { interview }\end{array}$ \\
\hline 25 & Serin $(2011)$ & university & North Cyprus & ANCOVA \\
\hline 26 & Behzadi, \&Manuchehri(2013 ) & High School & Iran & T-test \\
\hline 27 & Jewitt (2005) & Unspecified & England & $\begin{array}{l}\text { qualitative } \\
\text { approach }\end{array}$ \\
\hline 28 & AbuSeileek(2007) & university & Saudi Arabia & T-test \\
\hline 29 & Tsou, Wang, \&Tzeng(2004) & $\begin{array}{l}\text { elementary } \\
\text { school }\end{array}$ & Taiwan & $\mathrm{T}$-test \\
\hline
\end{tabular}


Another categorization consists of specifying the kind of technology used and the consequences of using it. Table 4 shows the consequences of using technology on students of a general course.

Table 4. Consequences of Using Technology on Students of a Course Other than English

\begin{tabular}{|c|c|c|c|c|}
\hline Code & Publication & $\begin{array}{l}\text { Educational } \\
\text { institution }\end{array}$ & $\begin{array}{l}\text { Type of } \\
\text { technology }\end{array}$ & ramifications \\
\hline 1 & Omidinia\&Masrom\&Selamat(2013) & Unspecified & ICT & $\begin{array}{lr}\text { facilitate } & \text { teaching } \\
\text { and } & \text { learning } \\
\text { activities } & \text { and } \\
\text { assist } & \\
\text { school } & \\
\text { management } & \end{array}$ \\
\hline 2 & Naba'h(2012) & $\begin{array}{l}\text { Secondary } \\
\text { school }\end{array}$ & $\begin{array}{l}\text { Macro- } \\
\text { Media Flash } \\
\text { Professional } \\
\text { Version } 6\end{array}$ & $\begin{array}{l}\text { scientific stream } \\
\text { students were } \\
\text { superior to literary } \\
\text { stream students in } \\
\text { their academic } \\
\text { achievement }\end{array}$ \\
\hline 3 & $\begin{array}{l}\text { Madhavaiah, Nagaraju, and Peter } \\
\text { (2013) }\end{array}$ & Unspecified & & $\begin{array}{lr}\text { By } & \text { using } \\
\text { technology, } & \\
\text { teaching } & \text { and } \\
\text { learning } & \text { are } \\
\text { facilitated } & \text { and } \\
\text { students } & \text { learn } \\
\text { faster and } & \text { easier } \\
\text { than before } & \\
\end{array}$ \\
\hline 4 & Soltani (2012) & Unspecified & $\begin{array}{l}\text { information } \\
\text { technology }\end{array}$ & $\begin{array}{l}\text { improve the } \\
\text { training needs, } \\
\text { educational } \\
\text { policies, } \\
\text { human resources } \\
\text { and curriculum } \\
\text { designs }\end{array}$ \\
\hline 5 & Attaran, Alias \&Siraj (2012) & Unspecified & & $\begin{array}{l}\text { smart schools on } \\
\text { integration into } \\
\text { curriculum, ICT } \\
\text { has not been } \\
\text { incorporated in the } \\
\text { everyday life of the } \\
\text { school }\end{array}$ \\
\hline 6 & Walsh (2010) & primary school & & $\begin{array}{l}\text { students' literacy } \\
\text { skill improve by } \\
\text { using technology }\end{array}$ \\
\hline 7 & Ong (2009) & primary school & & $\begin{array}{l}\text { The students in } \\
\text { smart schools have } \\
\text { positive attitude } \\
\text { toward science }\end{array}$ \\
\hline
\end{tabular}




\begin{tabular}{|c|c|c|c|c|}
\hline 8 & Nomass( 2013) & Unspecified & & $\begin{array}{l}\text { most of the } \\
\text { students prefer use } \\
\text { of technology, } \\
\text { especially } \\
\text { computers in } \\
\text { developing second } \\
\text { language skills }\end{array}$ \\
\hline 9 & Dlaska(2002) & University & $\begin{array}{l}\text { multimedia } \\
\text { technology }\end{array}$ & $\begin{array}{l}\text { affect } \\
\text { language learning, } \\
\text { and facilitate the } \\
\text { creation of } \\
\text { authentic learning } \\
\text { situations }\end{array}$ \\
\hline \multirow[t]{2}{*}{10} & Sharndama (2013) & Unspecified & ICT devices & $\begin{array}{l}\text { teacher can } \\
\text { manipulate } \\
\text { teaching process to } \\
\text { facilitate delivery, } \\
\text { learning activities }\end{array}$ \\
\hline & & & & $\begin{array}{l}\text { as well as } \\
\text { evaluation }\end{array}$ \\
\hline
\end{tabular}

Fallahkhair, $\quad$ Pemberton,\& Unspecified
Griffiths(2005) TAMALLE

supports learners in creating and managing their personal language knowledge

\begin{tabular}{|c|c|c|c|c|}
\hline 12 & Patel (2013) & - & & $\begin{array}{l}\text { technology affect } \\
\text { on teaching } \\
\text { communication } \\
\text { skills }\end{array}$ \\
\hline 13 & Liuzhi (2012) & university & $\begin{array}{l}\text { Multimedia } \\
\text { technology }\end{array}$ & $\begin{array}{l}\text { motivate } \\
\text { vocational } \\
\text { students' interests } \\
\text { in learning }\end{array}$ \\
\hline
\end{tabular}

As the table indicates, using different kinds of technology can have positive impacts on students' progress in different educational contexts in general. Utilizing ICT, for example, can facilitate teaching, learning, and evaluation. Multimedia technology can also create an authentic learning situation and motivate students towards learning. TAMALLE as another type of technology leads to students' management of their own language knowledge. Smart schools have also provided opportunities for students to adapt positive attitudes regarding science. Consequently, using technology motivates learners to acquire the materials more easily. Table 5 shows the results of using technology in an EFL/ ESL context. 
Table 5. Consequences of Using Technology on Students in an EFL/ ESL Context

\begin{tabular}{|c|c|c|c|c|}
\hline Code & Publication & $\begin{array}{l}\text { Educational } \\
\text { institution }\end{array}$ & $\begin{array}{ll}\text { Type } & \text { of } \\
\text { technology }\end{array}$ & ramifications \\
\hline 14 & $\begin{array}{l}\text { Kiliçkaya, } \\
\text { \&Seferoğlu(2013) }\end{array}$ & $\begin{array}{l}\text { Teacher training } \\
\text { course }\end{array}$ & $\begin{array}{l}\text { Software and } \\
\text { Web Based } \\
\text { Applications }\end{array}$ & $\begin{array}{l}\text { improve } \\
\text { students,ee } \\
\text { listening, writing } \\
\text { and grammar } \\
\text { skills }\end{array}$ \\
\hline 15 & $\begin{array}{l}\text { Naba'h, Hussain, } \\
\text { Omari, } \\
\text { \&Shdeifat(2009) }\end{array}$ & Secondary school & $\begin{array}{l}\text { Macro- Media } \\
\text { Flash } \\
\text { Professional } \\
\text { Version } 6\end{array}$ & $\begin{array}{l}\text { scientific stream } \\
\text { students were } \\
\text { superior to literary } \\
\text { stream students in } \\
\text { academic } \\
\text { achievement }\end{array}$ \\
\hline
\end{tabular}

\begin{tabular}{llll}
\hline Ghorbani,\&Marzban & High school & Microsoft & Office \\
(2013) & & facilitate grammar \\
& & Point 2007 & $\begin{array}{l}\text { learning both } \\
\text { inside and outside } \\
\text { the classroom }\end{array}$
\end{tabular}

\begin{tabular}{lllll}
\hline 17 & $\begin{array}{l}\text { Hassanabadi, \&Iranban } \\
(2013)\end{array}$ & High school & $\begin{array}{l}\text { Different kind of } \\
\text { technology }\end{array}$ & $\begin{array}{l}\text { Using technology } \\
\text { improve students } \\
\text { communicative } \\
\text { activities }\end{array}$ \\
\hline 18 & $\begin{array}{l}\text { Bahmani, Keshavarz, } \\
\text { \&Ghajari(2013) }\end{array}$ & $\begin{array}{l}\text { primary, junior } \\
\text { and high schools }\end{array}$ & $\begin{array}{l}\text { Different kind of } \\
\text { technology }\end{array}$ & $\begin{array}{l}\text { smart schools } \\
\text { improve social } \\
\text { skills of students }\end{array}$
\end{tabular}

Rostami, Akbari, \& junior high school Ghanizadeh(2014)
Power

Point Presentation and World Wide Web
Smart Schools

Programs have a positive and significant influence on learners' reading comprehension ability

\begin{tabular}{llll}
20 & $\begin{array}{l}\text { Smith, } \begin{array}{l}\text { Woody(2000) } \\
\text { Woniversity }\end{array} \\
\text { Traore\& }\end{array}$ & $\begin{array}{l}\text { color graphic } \\
\text { illustrations }\end{array}$ & $\begin{array}{l}\text { benefits students } \\
\text { with a high visual } \\
\text { orientation }\end{array}$ \\
\hline 21 & High school & $\begin{array}{l}\text { audio-visual } \\
\text { technologies }\end{array}$ & $\begin{array}{l}\text { help students in } \\
\text { learning English } \\
\text { more than the use } \\
\text { of single } \\
\text { technologies such } \\
\text { as televisions with } \\
\text { closed-captioning }\end{array}$
\end{tabular}




\begin{tabular}{|c|c|c|c|c|}
\hline 22 & Mehrgan(2012) & university & grammar software & $\begin{array}{l}\text { improve the } \\
\text { grammatical } \\
\text { ability of the } \\
\text { TEFL students }\end{array}$ \\
\hline 23 & Iravani, \& Tajik (2012) & High School & $\begin{array}{l}\text { Microsoft } \text { Office } \\
\text { Power } \\
\text { Point } 2007\end{array}$ & $\begin{array}{l}\text { has a great impact } \\
\text { on the students' } \\
\text { grammar learning }\end{array}$ \\
\hline 24 & Wang \& Smith (2013) & university & Internet (email) & $\begin{array}{lr}\text { improve } & \text { reading } \\
\text { and } & \text { grammar } \\
\text { ability } & \\
\end{array}$ \\
\hline 25 & Serin (2011) & university & $\begin{array}{l}\text { "Adobe } \\
\text { Photoshop" } \\
\text { program }\end{array}$ & $\begin{array}{l}\text { affect } \\
\text { achievements and } \\
\text { problem solving } \\
\text { skills of the } \\
\text { students }\end{array}$ \\
\hline 26 & $\begin{array}{l}\text { Behzadi \& Manuchehri } \\
\text { ( } 2013 \text { ) }\end{array}$ & High School & $\begin{array}{l}\text { Autograph and IQ } \\
\text { Board Software }\end{array}$ & $\begin{array}{l}\text { Using technology } \\
\text { increase creatively } \\
\text { students } \\
\text { mathematic skill } \\
\text { via traditional } \\
\text { teaching }\end{array}$ \\
\hline
\end{tabular}

Microsoft Word, impact

CD ROMs on students' text and $\mathrm{Of}$ mice and production and men [Penguin reading Electronics, and comprehension games (Kingdom hearts)

\begin{tabular}{|c|c|c|c|c|}
\hline 28 & AbuSeileek (2007) & university & $\begin{array}{l}\text { Microsoft Office } \\
\text { Power } \\
\text { Point }\end{array}$ & $\begin{array}{l}\text { computer-Based } \\
\text { grammar } \\
\text { instruction affect } \\
\text { on the acquisition } \\
\text { of Verb Tenses }\end{array}$ \\
\hline
\end{tabular}
(2004)

increase the quality of teaching and learning and improve students enjoyment and success

$30 \quad$ Khiyabani, Ghonsooly, High school \&Ghabanchi(2014)
Different kind of Effective in technology

acquisition and learning unknown vocabulary via traditional methods 
As the table illustrates many different kinds of technology were used to facilitate learning English including; power point, the internet, games, and audio visual devices. Students' listening, writing, and reading skills were improved and the technology was seen to have positive impact on student' grammar skill and vocabulary learning. Problem solving as one of the most significant strategies in language learning was improved via the program of Photoshop software. Generally speaking, utilizing technology in the EFL/ESL context provided enjoyable environment for students to learn English. Table 6 displays the number of participants (males and females) in each study and their age range. As indicated by the tables, the use of technology and the corresponding benefits are not restricted to any specific age or gender group.

Table 6. Number of Participants and their Age Range

\begin{tabular}{lllll}
\hline Code & Number & Male & Female & Age(average) \\
\hline 1 & 35 & 7 & 28 & 21 \\
2 & 10 & 4 & 6 & 15 \\
3 & 53 & - & - & 14 \\
4 & 64 & & 64 & 16 \\
5 & 80 & 40 & 40 & 20 \\
6 & 35 & 7 & 28 & 25 \\
7 & 127 & 127 & - & 20 \\
8 & 128 & 128 & - & 23 \\
9 & 70 & - & - & 10 \\
10 & 115 & - & - & 15 \\
11 & 3421 & 1973 & 1448 & 18 \\
12 & 212 & - & 212 & 15 \\
13 & 56 & 56 & - & 15 \\
14 & 80 & 80 & - & 20 \\
15 & 10 & 6 & 4 & 15 \\
16 & 124 & 124 & - & 14 \\
17 & 83 & 48 & 35 & 20 \\
\hline
\end{tabular}

\section{DISCUSSION AND CONCLUSIONS}

This review study was done to accomplish two goals: (a) to review the overall effectiveness of using technology in general education, (b) to investigate recent studies in language learning by using technology, (c) to discover effective outcomes due to using technology in general education, and (d) to examine effectiveness of using technology in language education. So, the results and implications of the study were summarized and discussed for future research and development efforts in TELL.

In terms of overall effectiveness of technology on learning, it was found that the employment of different kinds of technology can have tremendous impacts on students' progress in different educational contexts in general. The advantages range from facilitating teaching and to assessment and evaluation. Technology also improves the training needs, educational policies, human resources and curriculum designs. Besides, multimedia technology can create an authentic learning situation and motivate students towards learning. Smart schools have also provided opportunities for students to adapt positive attitudes regarding science. Consequently, using technology motivates learners to acquire the materials more easily

This review shows that technology in different forms can be used effectively in almost all areas of language education. Findings showed that modern technologies improve the quality of input, authenticity of communication, and provide more relevant and useful feedback. Many different kinds of technology were used to facilitate learning English including; power point, the internet, games, and audio visual devices. These technologies were shown to influence all language skills and sub-skills, i.e., listening, writing, reading, speaking, grammar, and vocabulary. Problem solving as one of the most significant strategies in language learning was also improved Overall, 
utilizing technology in the EFL/ESL context created pleasant atmosphere for students to learn English.

This review study has significant implications for future work. First, it shows that technology can have a positive effect on language learning. These impacts encompass a wide range of advantages and benefits. If we want to focus on using modern information and communication technologies to improve language learning, technology capacities need to be incorporated into pedagogical and curriculum systems for language learners rather than print material- based curriculum. Second, findings shows some each technology useful for each specific skill and su-skill, so it is essential to explore appropriate ways in using technology for different components od language and in different contexts or classes (Slaberry,2001). Third, as review releases that technology uses are effective in improving language learning when they are incorporated in teaching and learning process in classes. Forth, it was concluded that students of both genders and with a wide range of age groups seem to benefit from TELL.

\section{References}

[1] Abdallah Abu Naba'h, A. A., Hussain, J., Omari, A. A., \& Shdeifat, S. (2009). The effect of computer assisted language learning in teaching English grammar on the achievement of secondary students in Jordan. The International Arab Journal of Information Technology, 6 (4), 431-439.

[2] AbuSeileek, A. F., \&Rabab'ah, G. A. (2007). The effect of computer-based grammar instruction on the acquisition of verb tenses in an EFL context. The JALT CALL Journal, 3 (1), 59-80.

[3] Al-Seghayer, K. (2001). The effect of multimedia annotation modes on L2 vocabulary acquisition: A comparative study. Language Learning \& Technology, 5 (1), 202-232. Retrieved from http://ltt.msu.edu/vol5num1/alseghayer/default.html

[4] Attaran, M., Alias, N., \&Siraj, S. (2012). Learning Culture in a Smart School: A Case Study.Procedia - Social and Behavioral Sciences 64, 417-423.

[5] Bacon, S., \& Finnemann, M. (1990). A study of the attitudes, motives, and strategies of university foreign language students and their disposition to authentic oral and written input. The Modern Language Journal, 74, 459-473.

[6] Bahmani, R., Keshavarz, H., \&Ghajari, H. (2013). The effect of smart schools on the social skills of students.Interdisciplinary Journal of Contemporary Research in Business, 5 (7), 151159.

[7] Behzadi, M. H., \&Manuchehri, M. (2013).Examining creativity of students through smart board in learning mathematics.Mathematics Education Trends and Research, 2013, 1-7.

[8] Creswell, J. (1994). Research design: qualitative and quantitative approaches. London: Sage.

[9] Dlaska, A. (2002). Sites of construction: language learning, multimedia, and the international engineer. Computers \& Education, 39, 129-143.

[10] Fallahkhair, S., Pemberton, L., \& Griffiths, R. (2005). Dual device user interface design for ubiquitous language learning: mobile phone and interactive television (iTV). Proceedings of the 2005 IEEE International Workshop on Wireless and Mobile Technologies in Education.

[11] Ghorbani, S., \&Marzban, A. (2013).The effect of CALL on Iranian beginner EFL learners' grammar learning.Journal of Academic and Applied Studies, 3 (7), 15-25.

[12] Glass, G. (1977). Integrating findings: The meta-analysis of research. Review of Research in Education, 5, 351-379.

[13] Hassanabadi, K. N., \&Iranban, S. J. (2013). Proper and efficient teaching by implementing smart schools.Europian Online Journal of Natural and Social Sciences, 2 (3), 1684-1988. 
[14] Iravani, H., \& Tajik, M. (2012).The effect of software-assisted grammar teaching on learning grammar of Iranian male junior high school learners.Journal of Language and Translation, 3 (1), 23-28.

[15] Jewitt, C. (2005). Multimodality, "reading", and "writing" for the 21st century. Discourse: Studies in the Cultural Politics of Education, 26 (3), 315-331.

[16] Khiyabani, H., Ghonsooly, B., \&Ghabanchi, Z. (2014). Using multimedia in teaching vocabulary in high school classes.Journal of Advances in English Language Teaching, 2 (1), 1 33.

[17] Kiliçkaya, F., \&seferoğlu, G. (2013). The impact of CALL instruction on English language teachers' use of technology in language teaching. Journal of Second and Multiple Language Acquisition, 1 (1), 20-38.

[18] Hedges, L. V., \& Olkin, I. (1985). Statistical methods for meta-analysis. Orlando: Academic Press.

[19] Kelm, O. R. (1998). The use of electronic mail in foreign language classes. In K. Arens (Ed.), Language learning online (pp. 141-154). Austin, TX: The Daedalus Group Inc.

[20] Kitajima, R., \& Lyman-Hager, M. A. (1998). Theory-driven use of digital video in foreign language instruction. CALICO Journal, 16 (1), 37-48.

[21] Krashen, S. (1985). The input hypothesis: Issues and implications. London: Longman.

[22] Labrie, G. (2000). A French vocabulary tutor for the web. CALICO Journal, 17 (3), 475-499.

[23] Lafford, P. A., \& Lafford, B. A. (1997). Learning language and culture with the Internet. In R. M. Terry (Ed.), Technology-enhanced language learning. Lincolnwood, IL: The National Textbook Company.

[24] Liuzhi, Y. (2012). On the applications of multimedia in english teaching in vocational colleges. 2012 International Conference on Education Technology and Management Engineering Lecture Notes in Information Technology, 16, 1-4.

[25] Lee, L. (1998). Going beyond classroom learning: Acquiring cultural knowledge via online newspapers and intercultural exchanges via online chatrooms. CALICO Journal, 16 (2),

[26] Lou, Y., Abrami, P. C., \& d'Apollonia, S. (2001). Small group and individual learning with technology: A meta-analysis. Review of Educational Research, 71 (3), 449-521.

[27] Lyons, L. C. (1995a). Meta-analysis: Methods of accumulating results across research domains [web]. Retrieved December 20, 2001, from http://www.mnsinc.com/solomon

[28] Muyskens, J. A. (1998). New ways of learning and teaching: Focus on technology and foreign language education. Boston: Heinle \& Heinle.

[29] Madhavaiah G., Nagaraju, Ch., \& Peter, S. (2013). Importance of technology in teaching and learning English language.International Journal of Scientific Research and Reviews, 2 (3), 146154.

[30] Mehrgan, K. (2012). Computer-assisted language learning: a panacea for grammar development. Naba'h, A. A. (2012). The impact of computer assisted grammar teaching on EFL pupils' performance in Jordan. International Journal of Education and Development using Information and Communication Technology, 8(1), 71-90. 
[31] Nomass, B. B. (2013). The impact of using technology in teaching English as a second language.English Language and Literature Studies, 3 (1), 111-116. Advances in English Linguistics (AEL), 1 (2), 25-29.

[32] Nagata, N. (1993). Intelligent computer feedback for second language acquisition. The Modern Language Journal, 77, 330-339.

[33] Nutta, J. (1998). Is computer-based grammar instruction as effective as teacher-directed grammar instruction for teaching L2 structures? CALICO Journal, 16 (1), 49-61.

[34] Omidinia, S., Masrom, M., \&Selamat, H. (2013). An examination of the concept of smart school: an innovation to address sustainability. 2nd International Conference on Advances in Computer Science and Engineering, 326-329.

[35] Ong, E. T., \& Ruthven, K. (2009), The Effectiveness of Smart Schooling on Students' Attitudes Towards Science. Eurasia Journal of Mathematics, Science, and Technology Education, 5 (1), 35-45.

[36] Patel, C. (2013). Use of multimedia technology in teaching and learning communication skill: an analysis. International Journal of Advancements in Research \& Technology, 2 (7), 116-123.

[37] Pellettieri, J. (2000). Negotiation in cyberspace: The role of chatting in the development of grammatical competence. In R. Kern (Ed.), Network-based language teaching: Concepts and practice (pp. 59-86). Cambridge: Cambridge University Press.

[38] Rostami, S., Akbari, O., \& Ghanizadeh, A. (2014).The effect of smart school programs on EFL reading comprehension in an academic context. International Journal of Research Studies in Educational Technology, 4 (1). Doi: 10.5861/ijrset.2014.936,Available Online: 28 November 2014

[39] Serin, O. (2011). The effects of the computer-based instruction on the achievement and problem solving skills of the science and technology students.The Turkish Online Journal of Educational Technology, 10(1), 183-201.

[40] Sharndama, E. C. (2013). Application of ICTs in teaching and learning English (ELT) in large classes.Journal of Arts and Humanities, 2 (6), 34-39.

[42] Soltani, M. (2012).The structure of smart schools in the educational system.Journal of Basic and Applied Scientific Research, 2 (6), 6250-6254.

[43] Smith, S. M., \& Woody, P. C. (2000).Interactive effect of multimedia instruction and learning styles.Teaching of Psychology, 27 (3), 220-223.

[44] Salaberry, M. R. (2001). The use of technology for second language learning and teaching: A retrospective. The Modern Language Journal, 85 (1), 39-56.

[45] Shea, P. (2000). Leveling the playing field: A study of captioned interactive video for second language learning. Journal of Educational Computing Research, 22 (3), 243-263.

[46] Sinyor, R. (1997). An analysis of student behavior and error sources in an Italian CALL context. CALICO Journal, 14 (2-4), 35-50.

[47] Tsou, W., Wang, W., \&Tzeng, Y. (2006). Applying a multimedia storytelling website in foreign language learning.Computers \& Education, 47, 17-28.

[48] Traore, M., \&Blankson, L. K. (2011). Using literature and multiple technologies in ESL instruction.Journal of Language Teaching and Research,2 (3), 561-568.

[49] Thorton, P., \& Dudley, A. (1996). The CALL environment: An alternative to the language lab. CAELL Journal, 7 (4), 29-34. 
[50] Warschauer, M. (1998). Researching technology in TESOL: Determinist, instrumental, and critical approaches. TESOL Quarterly, 32 (4), 757-761.

[51] Weyers, J. R. (1999). The effects of authentic video on communicative competence. The Modern Language Journal, 83 (3), 339-349.

[52] Walsh, M. (2010). Multimodal literacy: What does it mean for classroom practice?.Australian Journal of Language and Literacy,33 (3), 211-239.

[53] Wang, S., \& Smith, S. (2013). Reading and grammar learning through mobile phones. Language Learning \& Technology, 17 (3), 117-134. 